\title{
PEREMPUAN DAN PERANNYA DALAM \\ PEMBANGUNAN KESEJAHTERAAN SOSIAL \\ (WOMEN AND ITS ROLE ON SOCIAL WELFARE DEVELOPMENT)
}

\author{
Ratih Probosiwi ${ }^{1}$
}

\begin{abstract}
Women are seen as second class citizens. The role of women in development is often questionable as being unfit and incapable. This paper attempts to analyze the gender is not only limited to the role and activities of men and women, but also their relationship. It also examines women in development, the role, position, and also increase its role in development. This paper emphasizes the empowerment of women in development, especially the development of social welfare. Enterprises group considered suitable for women, although potentially reducing the self-power. This paper is literature review through search of data and information from books, scientific articles, journal, genderrelated laws, and policies that tie. It's required gender mainstreaming policies and involved women in development. This policy will ensure that women are able to survive and carry out its social function properly.
\end{abstract}

Keywords: Women, Discrimination, Development, and Gender Mainstreaming

\begin{abstract}
Abstrak
Perempuan dipandang sebagai masyarakat kelas dua. Peran perempuan dalam pembangunan seringkali diragukan karena dianggap tidak layak dan tidak mampu. Tulisan ini mencoba menganalisis gender tidak hanya sebatas peran dan kegiatan antara laki-laki dan perempuan, tapi juga hubungan mereka. Selain itu juga mengkaji perempuan dalam pembangunan, peran, posisi, dan juga peningkatan perannya dalam pembangunan. Tulisan ini mengedepankan pemberdayaan perempuan dalam pembangunan, khususnya pembangunan kesejahteraan sosial. Usaha kelompok dinilai cocok bagi perempuan, walaupun berpotensi mengurangi daya diri. Tulisan ini merupakan kajian literatur melalui pencarian data dan informasi dari buku, karangan ilmiah, jurnal, dan peraturan perundangan terkait gender dan kebijakan yang mengikatnya. Diperlukan kebijakan yang mengarusutamakan gender dan melibatkan perempuan dalam pembangunan. Kebijakan ini akan memastikan perempuan mampu bertahan hidup dan menjalankan fungsi sosialnya dengan baik.
\end{abstract}

Kata Kunci: Perempuan, Diskriminasi, Pembangunan dan Pengarusutamaan Gender

\footnotetext{
${ }^{1}$ Peneliti, Balai Besar Penelitian dan Pengembangan Pelayanan Kesejahteraan Sosial (B2P3KS) Yogyakarta, Kementerian Sosial RI. Email: ratih.probo@depsos.go.id
} 


\section{PENDAHULUAN}

Sejak sepuluh tahun belakangan ini, kata gender telah memasuki perbendaharaan disetiap diskusi dan tulisan sekitar perubahan sosial dan pembangunan dunia ketiga. Demikian juga di Indonesia, hampir semua uraian tentang program pemberdayaan masyarakat maupun pembangunan di kalangan organisasi non-pemerintah diperbincangkan masalah gender. Istilah gender digunakan untuk menjelaskan antara laki-laki dan perempuan. Misalnya bahwa perempuan itu lemah lembut, cantik, emosional atau keibuan. Sementara laki-laki dianggap sebagai orang yag kuat, rasional, jantan, perkasa. Ciri dari sifat itu sendiri merupakan sifat-sifat yang dapat dipertukarkan. Semua hal yang dapat dipertukarkan antara sifat laki-laki dan perempuan, yang bisa berubah dari waktu ke waktu serta berbeda dari tempat yang satu ke tempat yang lainnya, maupun berbeda dari suatu kelas ke kelas yang lain, itulah yang kemudian dikenal sebagai konsep gender. Istilah ini tentu berbeda dengan istilah seks yang merupakan perbedaan jenis kelamin secara bologis yang tidak dapat dipertukarkan.

World Bank menyebutkan bahwa kesetaraan gender merupakan persoalan pokok pembangunan yang akan memperkuat kemampuan negara untuk berkembang, mengurangi kemiskinan dan memerintah secara efektif. Dalam konteks itulah jika negara kita mau membangun pemerintahan yang maju setidaknya memperhatikan masalah secara khusus yang berkaitan dengan kesetaraan gender (World Bank, 2001). Pelaksanaan otonomi daerah misalnya, peraturan daerah yang berkaitan dengan perempuan muncul tanpa komunikasi dengan perempuan itu sendiri dan berdampak negatif bagi perempuan (Bambang S, 2004). Kebijakan yang sedang hangat diperbincangkan yaitu Perda larangan "mengangkang” bagi perempuan yang membonceng sepeda motor. Dengan dalih kesopanan dan nilai agama kebijakan ini dibuat tanpa komunikasi dengan pihak perempuan sebagai objek kebijakan. Lembaga Studi dan Advokasi Masyarakat (LSAM) bahkan mengemukakan bahwa setidaknya ada 153 peraturan daerah (perda) yang diskriminatif kepada perempuan. Perdaperda tersebut dianggap bertentangan dengan HAM karena adanya pengekangan terhadap perempuan (Armandhanu \& Budiawati, 2013).

Perempuan justru dijadikan sebagai objek sasaran yang tidak menguntungkan bagi kemajuan dirinya. Padahal jika kebijakan yang dibuat adalah kebijakan yang berwawasan gender maka setiap pelaksanaan program selalu menggunakan indikator atau pertimbangan keseimbangan peran dan 
manfaat bagi laki-laki maupun perempuan, sejak tahap perencanaan, pelaksanaan, hingga pemantauan dan evaluasi. Dengan pendekatan ini pula setiap pelaksanaan program akan selalu menunjukkan bentuk kesetaraan, keadilan, demokratis dan transparasi yang dapat meningkatkan akuntabilitas kinerja pemerintahan.

World Summit for Social Development di Copenhagen pada tahun 1995 mengangkat kesetaraan gender sebagai strategi untuk pembangunan sosial ekonomi dan perlindungan lingkungan. Pada tahun 1995, The Fourth World Conference on Woman, di Beijing, mengungkap ulang pentingnya cara ini, dengan melukiskan agenda untuk memperkuat status perempuan dan mengadopsi sebuah deklarasi dan landasan kerja yang membidik untuk mengatasi rintangan untuk mencapai kesetaraan gender, dan menjamin partisipasi aktif perempuan dalam segala aspek kehidupan. Pemerintah dengan segenap masyarakatnya, dihadapkan dengan area kritis terkait kesenjangan gender (Jurnal Perempuan, 2011)

Dalam meningkatkan kesetaraan gender dan peran perempuan dalam pembangunan, Indonesia harus menghadapi banyak sekali tantangan. Masyarakat cenderung memandang perempuan sebagai masyarakat kelas dua, bahkan di lingkungan keluarga sekalipun. Anak laki-laki dipandang lebih baik dan membanggakan dibandingkan anak perempuan. Anak laki-laki lebih diberi kesempatan untuk bersekolah dan mengenyam pendidikan dibandingkan anak perempuan. Faktor sosial budaya masyarakat dan orang tua yang cenderung menggunakan tenaga anak perempuan untuk membantu urusan rumah tangga sering berakibat pada rendahnya kinerja akademik bahkan putus sekolah. Adanya pemikiran bahwa menyekolahkan anak perempuan merupakan investasi yang siasia. Selain itu juga rendahnya pendidikan dan pengetahuan ibu tentang gizi dan kesehatan mempenharuhi pada tingkat kesehatan anak, tingginya anak kematian ibu dan bayi disamping sebabkan pula oleh kemiskinan.

Pemerintah harus mulai dengan membuat kebijakan yang mengarusutamakan gender dan pelibatan peran perempuan dalam pembangunan. Selama ini, tak dapat dipungkiri bahwa peraturan perundangan yang ada di Indonesia mengalami bias gender. Meskipun pasal 27 UUD RI tahun 1945 menjamin kesamaan hak bagi seluruh warganegara di hadapan hukum, baik lakilaki maupun perempuan, masih banyak dijumpai materi dan budaya hukum yang diskriminatif terhadap perempuan dan tidak berkeadilan gender. 
Dari uraian diatas, diketahui bahwa bagaimanapun zaman telah berkembang; bagaimanapun peradaban manusia telah meningkat; bagaimanapun ilmu dan pengetahuan telah mengalami kemajuan yang pesat, peran perempuan dalam masyarakat kita masih saja dianggap sebagai manusia kelas dua, manusia setelah laki-laki, sang manusia pertama yang mempunyai kekuasaan sangat besar dalam kehidupan. Sehingga perlu diketahui mengenai peranan perempuan dalam pembangunan dan perkembangan gender dalam pembangunan.

\section{METODE}

Tulisan ini merupakan kajian literatur yang mencoba mengkaji literatur mengenai peranan perempuan dalam pembangunan kesejahteraan sosial terkait dengan isu kesenjangan gender yang tetap ada. Tulisan ini memberikan pemantapan dan penegasan tentang peran perempuan dalam pembangunan. Melalui literatur dan penelitian yang ada, tulisan ini mencoba untuk menganalisis gender tidak sebatas peran dan kegiatan antara laki-laki dan perempuan. Tulisan ini bertujuan untuk memberikan gambar perkembangan gender dari masa ke masa, peranan perempuan dalam pembagian kerja, dan posisi perempuan dalam pembangunan kesejahteraan social dan juga diharapkan dapat menjadi titik tolak perumusan kebijakan kesetaraan gender dan pemberdayaan perempuan.

\section{PEMBAHASAN}

\section{WiD, WaD, dan GaD}

Selama dua dekade, yakni (1970an-1980an) ada tiga pendekatan terhadap studi perempuan. Yaitu, WiD (Women in Development), WaD (Women and Development), dan GaD (Gender and Development) (Mosse, 1996).

WiD approach timbul pada awal tahun 1970an dalam publikasi Easter Boserup tentang Women's Role in Economics Development. Boserup menganalisis dampak perubahan dari masyarakat tradisional ke masyarakat modern pada laki-laki dan perempuan. WiD approach sangat dipengaruhi oleh pemikiran teori modernisasi, yang menganggap bahwa keterbelakangan perempuan lebih disebabkan karena faktor individu itu sendiri seperti pendidikan rendah. Oleh karena itu melalui pendidikan yang lebih baik akan dapat meningkatkan posisi perempuan dan mengintegrasikannya dalam proses pembangunan. Pengertian WiD ini kemudian digunakan oleh Women's Committee of Washington DC, dan selanjutnya banyak disuarakan oleh kaum feminist liberal Amerika (American Liberal Feminist), yang memberikan 
perhatian pada perlunya perubahanperubahan legal dan administratif untuk menjamin agar perempuan dapat berintegrasi dalam sistem pembangunan. Oleh karena itu, fokus WiD adalah para egaliter dan penetapan desain strategi pembangunan yang dapat mengurangi kerugian perempuan di sektor produktif dan mengakhiri diskriminasi. (Boserup, 1997)

WiD ini menjadi bagian dari diskursus pembangunan dan merupakan pendekatan dominan bagi pemecahan persoalan perempuan Dunia Ketiga. Gagasan WiD dianggap satu-satunya jalan guna memperbaiki status dan nasib berjuta-juta perempuan di Dunia Ketiga. Namun setelah kurang lebih sepuluh tahun berjalan, banyak orang mulai menyangsikannya dan mengajukan kritik mendasar terhadap konsep WiD. Kritik ini dipelopori oleh aliran feminisme. WiD dianggap sebagai bagian dari agenda Dunia Pertama untuk mendominasi Dunia Ketiga. Konsep WiD sendiri dianggap membawa bias feminis liberal, kelas menengah kulit putih, yang dianggap tidak memiliki kepentingan pembebasan perempuan.

Agenda utama program WiD adalah bagaimana melibatkan kaum perempuan dalam kegiatan pembangunan. Asumsinya, penyebab keterbelakangan perempuan adalah karena mereka tidak berpartisipasi dalam pembangunan.

Dengan cepat WiD menjadi satusatunya kebijakan yang berkaitan dengan perempuan di hampir semua negara Dunia Ketiga. Diskursus WiD dimulai ketika pemerintah Amerika mengeluarkan "The Percy Amendment to the 1973 Foreign Assistance Act" yang mencantumkan perlunya perhatian terhadap perempuan dalam pembangunan. Amandemen tersebut kemudian mempengaruhi PBB pada tahun 1974 yang kemudian memproklamirkan International Decade of Women (1976-1985). Dan sejak itulah, hampir serentak, pemerintah di negara Dunia Ketiga memasukkan agenda WiD dalam program pembangunan mereka. Departemen urusan peranan perempuan pun menjadi mode di hampir semua pemerintahan Dunia Ketiga. WiD senantiasa diajukan sebagai jawaban kaum Developmentalism atas kritik kaum feminis yang menganggap pembangunan telah mengabaikan perempuan.

Pada saat WiD lahir, banyak orang telah menilai bahwa gagasan ini justru menjinakkan dan mengerangkeng perempuan Dunia Ketiga ketimbang membebaskannya. Jadi, dapat disimpulkan bahwa sesungguhnya WiD merupakan strategi dan diskursus developmentalism untuk melanggenggkan dominasi dan penindasan perempuan di 
Dunia Ketiga, melalui upaya penjinakan (cooptation) dan pengekangan (regulation) perempuan. Berarti pada dasarnya menghindari upaya emansipasi. Oleh karena itu, WiD diragukan mampu memacu proses transformasi.

Transformasi sosial yang dimaksud adalah semacam proses penciptaan hubungan yang secara fundamental merupakan sesuatu yang baru dan lebih baik. Yang dimaksud hubungan disini adalah hubungan ekonomi yang eksploitatif menuju struktur tanpa eksploitasi, hubungan kultur hegemonik perlu diubah menjadi struktur politik yang nonrepresif, dari struktur gender yang mendominasi perempuan menuju ke struktur yang membebaskan. Dengan demikian demokratisasi merupakan alternatif dari proses transformasi sosial. Jika WiD bertujuan memproses persamaan kaum laki-laki dan perempuan, maka transformasi gender merupakan gerakan pembebasan perempuan dan lakilaki dari sistem dan struktur yang tidak adil. Dengan demikian transformasi gender merupakan upaya pembebasan dari segala bentuk penindasan baik itu struktural maupun personal, kelas, warna kulit dan ekonomi internasional. Tujuan gerakan transformasi gender tidak sekadar memperbiki status perempuan yang indikatornya menggunakan norma laki- laki melainkan memperjuangkan martabat dan kekuatan perempuan.

WaD approach timbul pada pertengahan tahun 1970an dan dipengaruhi oleh neo marxist feminist approach. Fokus utama dari pendekatan ini adalah melihat pada hubungan perempuan dalam proses pembangunan. Proses pembangunan sering menyebabkan marginalisasi kaum perempuan. Ini disebabkan adanya struktur sosial, ekonomi, dan politik yang tidak adil di masyarakat. Keterbelakangan perempuan dianggap akibat adanya struktur yang tidak adil tersebut.

Proses marginalisasi, yang mengakibakan kemiskinan, sesungguhnya banyak sekali terjadi dalam masyarakat dan negara yang menimpa kaum laki-laki dan perempuan, yang disebabkan oleh beberapa kejadian, misalnya penggusuran, bencana alam, atau proses eksploitasi. Namun ada salah satu bentuk pemiskinan atas satu jenis kelamin tertentu, dalam hal ini perempuan, disebabkan oleh gender. Ada beberapa perbedaanjenis dan bentuk, tempat dan waktu serta mekanisme proses marginalisasi kaum perempuan karena perbedaan gender tersebut. Dari segi sumbernya bisa berasal dari kebijakan pemerintah, keyakinan, tafsiran agma, keyakinan tradisi dan kebiasaan atau bhkan asumsi ilmu pengetahuan. 


\begin{abstract}
Banyak studi telah dilakukan dalam rangka membahas program pembangunan pemerintah yang menjadi sebab kemiskinan kaum perempuan. Misalnya, program swa-sembada pangan atau revolusi hijau (green revolution)
\end{abstract} secara ekonomis telah menyingkirkan kaum perempuan dari pekerjaannya sehingga memiskinkan mereka. Di Jawa misalnya, program revolusi hijau dengan memperkenalkan jenis padi unggul yang tumbuh lebih rendah, pendekatan panen dengan sistem tebang menggunakan sabit, tidak memungkinkan lagi penggunaan aniani, padahal alat tersebut melekat dan digunakan oleh kaum perempuan. Akibatnya banyak kaum perempuan miskin di desa termarginalisasikan, yakni semakin miskin dan tersingkir karena tidak mendapatkan pekerjaan di sawah pada musim panen. Berarti revolusi hijau dirancang tanpa mempertimbangkan aspek gender.

Sedangkan GaD approach muncul pada tahun 1980an dan pendekatan ini sangat dipengaruhi oleh socialist feminist approach. Pendekatan ini dikenal sebagai upaya pemberdayaan perempuan. GaD lebih melihat perempuan sebagai agen perubahan daripada objek yang pasif dalam pembangunan. Oleh karena itu, perempuan harus mampu mengorganisir dirinya dalam proses pembangunan. Pembangunan harus dilihat sebagai usaha untuk memandirikan dan membangun kekuatan internal kaum perempuan. Pendekatan ini memiliki ketegangan antara kebutuhan kesadaran feminis di satu pihak dan kebutuhan menjaga integritas materialisme Marxisme dipihak lain, sehingga analisis patriarki perlu ditambahkan dalam analisis mode of production.

Mereka mengkritik asumsi umum, hubungan antara partisipasi perempuan dalam ekonomi memnag perlu, namun tidak selalu menaikkan status perempuan. Rendahnya tingkat partisipasi berkorelasi dengan rendahnya status perempuan.Tetapi keterlibatan perempuan justru dianggap menjerumuskan perempuan, karena mereka akan dijadikan budak (virtual slaves). Bagi feminis sosialis meningkatnya partisipasi ekonomi perempuan lebih berakibat pada peran antagonisme seksual ketimbang status.

Gender berkaitan dengan konstruksi sosial terhadap perempuan . Masyarakat sering menganggap perempuan sebagai kelompok masyarakat lemah dan terbatas untuk melakukan pekerjaan-pekerjaan domestik atau rumah tangga. Sedangkan laki-laki sebagai makhluk yang superior dan bertugas untuk urusan-urusan non domestik. Dalam pandangan tradisi patriarkhi, perempuan secara struktural berada di bawah lakilaki, dan kondisi ini secara struktural dan 
kultural tidak menguntungkan kaum perempuan. Untuk itu, para penganut $\mathrm{GaD}$ menekankan perlunya pemberdayaan dalam diri perempuan dan merubah konstruksi sosial di atas.

Pendekatan ini memahami tujuan pembangunan bagi perempuan dalam pengertian kemandirian dan kekuatan internal, dan sedikit banyak lebih menekankan pada pembuatan undangundang yang berkenaan dengan kesamaan antara laki-laki dan perempuan ketimbang pemberdayaan perempuan itu sendiri untuk berusaha mengubah dan mentransformasikan struktur yang sangat bertentangan dengan mereka. Pendekatan ini mengakui perlunya pembuatan undang-undang yang bersifat mendukung, berpendapat bahwa perkembangan organisasi perempuan, yang mengarah pada mobilisasi politik, peningkatan kesadaran dan pendidikan rakyat, merupakan syarat penting bagi perubahan sosial yang berkelanjutan.

\section{Gender dan Pembagian Kerja Perempuan}

Pada saat manusia masih berpikir dengan sangat sederhana, mereka belajar dari apa yang mereka lihat dalam hidup. Mereka membutuhkan pembagian kerja untuk kelangsungan hidup, kemudian dimulailah pembagian kerja atas dasar biologis. Sejarah mencatat bahwa pada zaman ini, terjadi pembagian kerja berdasarkan jenis kelamin. Dari sini kemudian muncul perbedaan jenis pekerjaan luar (publik) dan pekerjaan dalam (domestik). Tersosialisasi oleh lingkungan hidupnya, maka hidup perempuan cenderung berkelompok, mengelola makanan dan obat-obatan. Ini berbeda dengan laki-laki yang bekerja diluar dengan bebas. Lingkungan hidup laki-laki mensosialisasikan hidupnya berpindah-pindah.

Ketika manusia mulai mengenal peternakan, terjadi perubahan sistem masyarakat ke arah patriarkhi. Masyarakat patriarkhi adalah masyarakat yang mempunyai rujukan sistem yang berdasarkan pada kesepakatan laki-laki, dimana dalam masyarakat tersebut kondisi perempuan sangat termarginalisasikan dan dipinggirkan melalui kerja-kerja domestik (Nurlian \& Daulay, 2008). Peminggiran perempuan dalam masyarakat patriarkhi dilihat dari sisi pola pembagian kerja antara laki-laki dan perempuan terwujud dengan sangat jelas, dimana laki-laki lebih banyak mendominasi sektor publik, sedangkan perempuan pada sektor domestik. Pekerjaan yang dilakukan oleh perempuan sangat sedikit mendapatkan penghargaan. Hal ini diakibatkan oleh kontruksi sosial berdasarkan tubuh perempuan dan laki-laki. Pembagian yang tidak seimbang ini banyak dirasakan oleh 
kaum perempuan hingga melahirkan beban kerja. Dengan demikian, kondisi kaum perempuan banyak diintimidasi oleh sistem patriarkhi, sedangkan kaum lakilaki lebih banyak menguasai pekerjaan disektor publik.

Pembagian kerja berdasarkan gender adalah semua konsep dan praktik pada masyarakat tertentu yang membagi peranan dan pekerjaan berdasarkan jenis kelamin. Pembagian kerja berdasarkan jenis kelamin dapat dibagi menjadi tiga jenis yaitu produksi, reproduksi, dan komunitas atau yang disebut juga tiga peran gender (triple role) (Hungu, 2010). Kerja produksi yaitu semua pekerjaan yang berkaitan dengan produksi barang dan jasa untuk mendapatkan penghasilan. Jenis pekerjaan ini saat ini lebih terbuka, baik itu untuk laki-laki maupun perempuan. Kerja reproduksi adalah pekerjaan yang berkaitan dengan perawatan dan pemeliharaan rumah tangga, ini lebih menunjuk dan lebih banyak dilakukan oleh perempuan. Sedangkan kerja komunitas adalah kegiatan yang dilakukan untuk aktivitas kemasyarakatan yang dalam pelaksanaannya dapat dilakukan oleh lakilaki maupun perempuan. Dari ketiga jenis pekerjaan tersebut, diketahui bahwa perempuan berada pada ketiga kotak pekerjaan tersebut. Perempuan ternyata lebih bebas dalam memilih pekerjaan walaupun dalam pelaksanaannya seringkali tetap terpinggirkan dan dibatasi. Analisis gender tidak hanya melihat perbedaan peran dan kegiatan antara laki-laki dan perempuan, tetapi juga melihat relasi mereka. Dari relasi ini akan nampak status perempuan dan laki-laki. Analisis ini tidak hanya menanyakan siapa dan bekerja apa, tetapi juga siapa yang mengambil keputusan apa, siapa yang mendapatkan manfaat, siapa yang menguasai sumber-sumber produksi, siapa yang mengontrol kehidupan. Pembagian kerja gender dalah pola pembagian kerja antara pasangan suami istri yang disepakati bersama, serta didasari oleh sikap yang saling memahami dan saling mengerti (Nurlian \& Daulay, 2008).

Pada tahun 2000, di Indonesia tercatat sekitar 71 juta perempuan dan 69 juta laki-laki yang berada dalam usia kerja, meskipun tingkat partisipasi angkatan kerja laki-laki secara konsisten melebihi tingkat partisipasi angkatan kerja perempuan. Pada tahun 2000 juga tercatat baru 51 persen perempuan tetapi 84 persen laki-laki berusia 15 tahun ke atas yang berada dalam angkatan kerja, dengan perempuan mencakup 38 persen dari angkatan kerja keseluruhan. Secara tidak proporsional, tenaga kerja perempuan jauh lebih banyak dijumpai dalam perekonomian informal daripada tenaga kerja laki-laki. Kira-kira 65\% dari seluruh 
pekerja dalam perekonomian informal adalah perempuan (ILO Jakarta, 2003).

Partisipasi angkatan kerja menurut jenis kelamin dijelaskan pada Tabel 1. rendah dibandingkan angka Indeks Pembangunan Manusia (IPM) di semua kabupaten/kota. Hal ini dapat memberikan gambaran bahwa persoalan kesenjangan

Tabel 1. Partisipasi Angkatan Kerja Menurut Jenis Kelamin Tahun 2000

\begin{tabular}{lccc}
\hline & Perempuan & Laki-laki & $\begin{array}{c}\text { Perempuan } \\
\text { terhadap } \\
\text { Total (\%) }\end{array}$ \\
\hline Penduduk Usia Kerja 15+ & 71.333 .006 & 69.837 .799 & $50,5 \%$ \\
\hline $\begin{array}{l}\text { Tingkat Partisipasi Angkatan } \\
\text { Kerja }\end{array}$ & $51,7 \%$ & $84,2 \%$ & $38,9 \%$ \\
\hline $\begin{array}{l}\text { Tingkat Partisipasi Angkatan } \\
\text { Kerja Menurut Umur }\end{array}$ & & & \\
\hline Umur 15 - 24 & $43,1 \%$ & $60,8 \%$ & $42,3 \%$ \\
\hline Umur 25 - 54 & $58,1 \%$ & $97,6 \%$ & $37,5 \%$ \\
\hline Umur > 55 & $42,5 \%$ & $73,4 \%$ & $37,7 \%$ \\
\hline Sumb : Sit & & \\
\hline
\end{tabular}

Sumber : Situasi Angkatan Kerja di Indonesia, BPS (dalam ILO Jakarta, 2003)

Pengangguran juga masalah yang dihadapi perempuan. Perempuan menghadapi kendala yang lebih besar daripada laki-laki untuk menemukan pekerjaan. Disamping itu, tingkat pengangguran di kalangan perempuan pada tingkat pendidikan yang lebih tinggi relatif lebih besar daripada laki-laki. Data dari ILO (2003) menunjukkan bahwa persentasi perempuan yang menganggur sebanyak $42,5 \%$ padahal $54 \%$ dari pekerja dengan ijazah Diploma I, II, III, dan ijazah akademi dan $51 \%$ dari pekerja lulusan universitas yang menganggur adalah perempuan.

Kesenjangan gender terjadi hingga sampai tingkat kabupaten/kota (BPS DKI Jakarta, 2013). Hal ini ditunjukkan melalui besaran angka Indeks Pembangunan Gender (IPG) yang lebih gender masih terjadi di semua wilayah. IPG merupakan indeks pencapaian kemampuan dasar pembangunan manusia yang sama seperti IPM dengan memperhatikan ketimpangan gender. IPG digunakan untuk mengukur pencapaian dalam dimensi yang sama dan menggunakan indikator yang sama dengan IPM, namun lebih diarahkan untuk mengungkapkan ketimpangan antara lakilaki dan perempuan.

Berdasarkan Human Development Report Tahun 2002, IPG Indonesia menempati peringkat 91 dari 173 negara, sedangkan IPM berada di peringkat 110 dari 173 negara. Ini masih tertinggal dibanding negara lain di ASEAN, misalnya Malaysia, Thailand, dan Filipina yang masing-masing berada pada peringkat 59, 70, dan 77 untuk IPM, dan 
pada peringkat 54, 60, dan 63 untuk IPG. Untuk itu diperlukan kebijakan dan program yang dapat mengintegrasikan pengalaman, aspirasi, kebutuhan, dan permasalahan perempuan dan laki-laki ke dalam perencanaan, pelaksanaan, pemantauan, dan evaluasi pada seluruh kebijakan dan program pembangunan nasional, di samping meningkatkan kualitas hidup perempuan itu sendiri.

\section{Perempuan dan Pembangunan}

\section{Kesejahteraan Sosial}

Dalam berbagai kajian, ditemukan bahwa masalah kemiskinan tidak saja mengenai masalah ketidakadilan sosial ekonomi, tetapi juga masalah kesenjangan antara laki-laki dan perempuan. Atas dasar itulah, isu kemiskinan kemudian diperluas, tidak sekedar persoalan teknis atau ekonomi. Dalam program pengentasan kemiskinan, perempuan ditempatkan sebagai subjek sekaligus objek dalam rangka meningkatkan kemampuan, peranan, dan kedudukannya sebagai penyangga penghidupan dan kehidupan keluarga serta berperan dalam berbagai usaha kesejahteraan sosial.

Kesenjangan yang terjadi antara laki-laki dan perempuan juga dipengaruhi oleh faktor sosial budaya. Kesenjangan partisipasi menurut jenis kelamin, baik program pemberdayaan perempuan rawan sosial ekonomi, keluarga fakir miskin, KAT, maupun pemberdayaan anak terlantar lebih banyak dipengaruhi faktor sosial budaya yang berkembang di masyarakat antara lain nilai dan sikap yang dianut oleh sebagian besar warga masyarakat. Laki-laki masih dianggap sebagai penopang ekonomi keluarga dan pengambil keputusan, sedangkan perempuan sebagai ibu rumah tangga. Padahal jumlah perempuan sebagai kepala rumah tangga juga menunjukkan angka yang tinggi. Perempuan sebagai pribadi memiliki kesempatan yang sama untuk meningkatkan kapasitas terutama dalam peningkatan kesejahteraan sosialnya.

Dalam rangka meminimalisir kesenjangan antara laki-laki dan perempuan serta untuk mengarusutamakan gender dalam pembangunan kesejahteraan sosial, Kementerian Sosial telah merintis berbagai usaha, antara lain:

1. Mengeluarkan Keputusan Menteri Sosial RI Nomor 36 tahun 1999 tentang Pola Pendataan Kesejahteraan Sosial terpilah berdasarkan jenis kelamin

2. Membentuk focal point yang berfungsi memfasilitasi dan membantu pengarusutamaan gender dalam sektor dan menjadi penanggungjawab bagi kepentingan gender di 
unit/kementerian. Walaupun tidak SK yang dikelyarkan, namun penunjukan langsung secara informal telah dilakukan

3. Mengeluarkan SK Menteri Sosial RI Nomor 07/PEGHUK/2002 tentang Pokja Pengarusutamaan Gender bidang Kesejahteraan Sosial Balatbangsos Nomor 01/PPJ/KSM/I/Tahun 2002 tentang dibentuknya Tim Teknis Pokja Bidang Kesejahteraan Sosial

5. Melakukan analisis gender untuk Repeta 2003 pada Program Pengembangan Potensi Kesejahteraan Sosial dan Pengembangan Sistem Informasi Masalah-masalah Sosial.

Di Indonesia, kebijakan yang diambil oleh pemerintah untuk mewujudkan kesetaraan dan keadilan gender telah ditetapkan melalui GBHN 1999, UU Nomor 25 Tahun 2000 tentang Program Pembangunan Nasional (Propenas 2000-2004), dan dipertegas dalam instruksi Presiden Nomor 9 tahun 2000 tentang Pengarustamaan Gender (PUG). Disamping itu beberapa Undang Undang Lainnya juga mendukung kesetaraan gender, antara lain UU Nomor 7 tahun 1984 tentang Pengesahan Konvensi mengenai penghapusan segala bentuk diskriminasi terhadap perempuan; UU Nomor 23 tahun 2004 tentang Penghapusan Kekerasan Dalam Rumah Tangga; dan UU Nomor 21 tahun 2007 tentang Pemberantasan Tindak Pidana Perdagangan Orang. Pemerintah juga membuat Rancangan Undang-Undang Kesetaraan dan Keadilan Gender (RUU $\mathrm{KKG)} \mathrm{yaitu} \mathrm{salah} \mathrm{satu} \mathrm{RUU} \mathrm{yang} \mathrm{dibahas}$ dalam Program Legislasi Nasional (Prolegnas) 2009-2014, yang diharapkan mampu menjadi landasan hukum mengenai penetapan dan penyelenggaraan Kesetaraan dan Keadilan Gender oleh Lembaga Negara di Indonesia.

Kiprah perempuan dalam kegiatan pembangunan lebih mengacu kepada program yang sesuai dengan tuntutan pembangunan yang tertuang dalam program kerja organisasi yang harus dikembangkan sesuai dengna komitmen sutau organisasi di tingkat nasional, regional, maupun internasional yang disusun untuk periode tertentu. Peranan perempuan dalam pembangunan ditandai dengan partisipasi perempuan dalam mengisi pembangunan di semua bidang pembangunan. Keberhasilan kiprah perempuan dalam pembangunan hanya terfokus dalam "kepentingan kesejahteraan perempuan" saja (women's welfare concerns) karena bidang-bidang yang dikembangkan terbatas dalam upaya meningkatkan kesejahteraan perempuan 
dan akses mereka terhadap sumber dan manfaat. Dengan demikian program yang dilakukan belum dinilai sebagai "proses pembangunan perempuan" atau isu pembangunan perempuan. Para ahli justru cenderung menggunakan konsep "women's empowerment" yaitu usaha peningkatan kemampuan perempuan.

Women's empowerment terkadang disebut juga sebagai pemberdayaan perempuan. Pemberdayaan perempuan mengacu pada upaya aktualisasi potensi yang sudah dimiliki perempuan. Pendekatan pemberdayaan yang berpusat pada manusia (people centered development) melandasi wawasan pengelolaan sumber daya lokal yang menekankan pada teknologi pembelajaran sosial dan strategi perumusan program. Kemampuan perempuan perlu ditingkatkan melalui penguasaan ilmu pengetahuan dan teknologi, keterampilan dan ketahanan mental dan spiritual agar dapat memanfaatkan kesempatan berperan aktif di segala bidang termasuk dalam proses pengambilan keputusan serta mampu menghadapi perubahan di masyarakat dan dunia internasional (Ayu, 1997).

Pemberdayaan perempuan dimulai dari kesadaran pribadi perempuan itu sendiri. Setiap manusia, tidak terkecuali perempuan, diciptakan dengan kekuatan pribadi. Kekuatan pribadi dan kekuatan kelompok ini bila direfleksikan dengan baik maka dapat membangkitkan semangat dari dalam diri kita. Faktanya, perempuan Indonesia dilihat sebagai investasi tenaga pembangunan, sehingga peran sertanya sangat diharapkan. Dengan demikian, perempuan Indonesia menjadi lebih berat tanggung jawabnya dalam melaksanakan pembangunan, yang semua keputusannya hampir diambil oleh lakilaki.

Pemberdayaan perempuan merupakan bagian dari pembangunan sumber daya manusia, dan ditujukan untuk meningkatkan status, posisi, dam kondisi perempuan agar dapat mencapai kemajuan yang setara dengan laki-laki, serta membangun generasi yang berkualitas. Pemberdayaan perempuan merupakan prioritas pembangunan, meliputi kualitas hidup perempuan di bidang kesehatan, pendidikan, ekonomi dan politik yang selama ini masih rendah dan rentan diskriminasi serta eksploitasi. Perempuan pedesaan yang dekat dengan sumber pangan dan budaya, memegang peran yang penting, yaitu potensinya besar untuk mendapatkan alternatif, menggali nilai-nilai budaya yang dapat melestarikan alam dan lingkungan hidup. Berbagai kemacetan di dunia modern, memacu kreativitas manusia untuk mendapatkan jalan keluar. Upaya dilakukan untuk menemukan alternatif dan potensi yang 
selama ini tidak terpikirkan sama sekali. Berbagai bentuk eksploitasi kekayaan alam, atas nama pembangunan, memberikan berbagai implikasi negatif. Sementara keperempuanan memberikan kemungkinan untuk eksplorasi, pengembangan dari berbagai cara, sehingga ideologi pembangunan tidak kontraproduktif dengan lingkungan alam itu sendiri. Kebijakan dalam pelaksanaan sasaran pembangunan perempuan meliputi beberapa hal berikut.

1. Peningkatan kualitas perempuan sebagai sumber daya pembangunan

2. Peningkatan kualitas dan perlindungan tenaga kerja perempuan

3. Peningkatan peran ganda perempuan dalam keluarga dan masyarakat

4. Pengembangan iklim sosial dan budaya yang mendukung kemajuan perempuan

5. Pembinaan kelembagaan dan organisasi perempuan (Ayu, 1997).

Konsep pembangunan

berkelanjutan, sangat cocok untuk dapat dikembangkan dan dijalankan oleh perempuan. Kaum perempuan dapat membuat kelompok untuk mengkaji informasi dunia yang datangnya sangat cepat, khususnya dalam menghadapi pasar bebas, budaya konsumtif akan masuk juga sampai ke pedesaan, sebagai pembuka jalan keberhasilan kepaitalisme. Kelompok perempuan pedesaan dapat berperan sebagai tameng, perisai, untuk menahan supaya budaya dan alam pedesaan tidak rusak oleh arus konsumtif. Peran ini sesuai dengan perempuan pada zaman matriarkhat. Kelompok perempuan pedesaan juga mempunyai tugas menemukan kembali serta memelihara budaya yang ada di desa, yang berkaitan dengan pangan, obat-obatan serta menilai kehidupan. Cerita rakyat dan upacara selamatan yang mendorong spiritualitas hidup di masyarakat, perlu digali kembali dan dipelihara. Hanya melalui kelompok dan solidaritas dengan kelompok lain, gerakan perempuan untuk melaksanakan pembangunan yang berkelanjutan, yang lebih berwawasan lingkungan dan budaya dapat terlaksana.

\section{SIMPULAN}

Untuk mencapai target kesetaraan gender, kebijakan yang diambil harus berfokus pada mewujudkan persamaan akses pendidikan yang bermutu dan berwawasan gender bagi semua anak lakilaki dan perempuan, pemberian kesempatan pendidikan gratis adalah langkah menurunkan tingkat buta huruf. Penurunan tingkat buta huruf juga meliputi penduduk dewasa terutama 
penduduk perempuan. Langkah ini dapat ditempuh melalui pendidikan sekolah dan luar sekolah, pendidikan penyetaraan, serta pendidikan baca tulis fungsional bagi penduduk dewasa. Peningkatan kemampuan lembaga pendidikan dalam mengelola dan mempromosikan pendidikan yang berwawasan gender juga penting dilakukan untuk penguatan faktor eksternal. Selain itu juga melalui peningkatan koordinasi, informasi, dan edukasi dalam rangka pengarusutamaan pendidikan berwawasan gender.

Kelompok Usaha Bersama (Kube) atau Jaminan Kesejahteraan Sosial berbasis gender dapat menjadi alternatif penyetaraan gender terutama pada sektor perekonomian. Penguatan faktor ekonomi perempuan akan meningkatkan posisi tawar di keluarga dan masyarakat. Model Pemberdayaan Wanita Rawan Sosial Ekonomi melalui Kelompok Sosial Usaha Ekonomi Produktif yang dikembangkan oleh Balai Besar Penelitian dan Pengembangan Pelayanan Kesejahteraan Sosial (B2P3KS) Yogyakarta merupakan salah satu kebijakan pembangunan berwawasan gender. Dengan sasaran perempuan yang rawan secara sosial ekonomi, program ini diharapkan mampu meningkatkan kemampuan perempuan untuk memahami, mengakses, dan memanfaatkan setiap bentuk peluang (dengan indikator dapat mengimplementasikan) kegiatan ke dalam kelembagaan kelompok yaitu berkreativitas dan memiliki inovasi pengetahuan dan keteramilan usaha dalam memperbaiki ekonomi keluarga. Pengarusutamaan gender dalam pembangunan, khususnya pembanguan kesejahteraan sosial akan memastikan perempuan mampu bertahan hidup dan menjalankan fungsi sosialnya dengan baik. Peningkatan kesejahteraan ekonomi akan meningkatkan posisi tawar perempuan dalam kehidupan masyarakat sehingga fungsi sosial dan kesejahteraan sosialnya terpenuhi. Segala bentuk pelibatan dan pemberdayaan perempuan tetap harus mempertimbangkan kodrat alami perempuan itu sendiri dan tidak berarti bersaing dengan laki-laki. Penyetaraan gender haruslah saling mengisi dan menghargai satu sama lain.

\section{DAFTAR PUSTAKA}

Alfian. (1986). Transformasi Sosial Budaya Dalam Pembangunan. Universitas Indonesia-Press : Jakarta

Armandhanu, D., \& Budiawati, A. D. (2013, January 9). ELSAM: Lebih dari Seratus Perda Diskriminatif pada Perempuan. Dipetik January 16, 2013, dari vivanews: http://nasional.news.viva.co.id/news/r ead/380865-elsam--lebih-dari-seratusperda-diskriminatif-pada-perempuan

Ayu, M. R. (1997). Cahaya Rumah Kita. Bandung: Penerbit Mizan. 
Bambang S, E. (2004, January 12). Otonomi Daerah Masih Mengesampingkan Peran Perempuan. Dipetik August 26, 2005, dari Jurnal Perempuan: http://www.jurnalperempuan.com/yjp .jpo/?act=berita\% $7 \mathrm{C}-277 \% 7 \mathrm{CN}$

Boserup, E. (1997). Women's Role in Economic Development. London: Earthscan.

BPS DKI Jakarta. (2013, Januari 2). Indeks Pembangunan Gender dan Indeks Pemberdayaan Gender Provinsi DKI Jakarta Tahun 2011. Berita Resmi Statistik . 2013, DKI Jakarta, Indonesia: BPS DKI Jakarta.

Budiman, Arief. (2000). Teori Pembangunan Dunia Ketiga. Gramedia Pustaka Utama : Jakarta

Faqih, Mansour. (1996). Analisis Gender dan Transformasi Sosial. Pustaka Pelajar : Yogyakarta

Hungu, F. T. (2010, August 16). Pembagian Kerja Berdasarkan Gender. Dipetik January 15, 2013, dari Genderpedia: genderpedia.blogspot.com/2010/08/pe mbagian-kerja-berdasarkangender.html

ILO Jakarta. (2003). Strategi Pengarusutamaan Gender. Jakarta: Kantor Perburuhan Internasional.

Jurnal Perempuan. (2011, May 25). Millennium Development Goals dan Gender Mainstreaming. Dipetik December 13, 2012, dari Jurnal Perempuan: jurnalperempuan.com /2011/05/millennium-developmentgoals-dan-gender-mainstreaming/

Nurlian, \& Daulay, H. (2008). Kesetaraan Gender dalam Pembagian Kerja pada Keluarga Petani Ladang (Studi Kasus Analisa Isu Gender pada Keluarga Petani Ladang di Desa Cot Rambong, Kecamatan Kuala, Kabupaten Nagan
Raya, NAD). Jurnal Harmoni Sosial, Januari 2008 Volume II No 2, 76-82.

Mosse, Julia Cleves. (1993). Gender dan Pembangunan. Pustaka Pelajar: Yogyakarta

Murniati, A.Nunuk P.. (2004). Getar Gender. Indonesiatera : Magelang

Nurlian, \& Daulay, H. (2008). Kesetaraan Gender dalam Pembagian Kerja pada Keluarga Petani Ladang (Studi Kasus Analisa Isu Gender pada Keluarga Petani Ladang di Desa Cot Rambong, Kecamatan Kuala, Kabupaten Nagan Raya, NAD). Jurnal Harmoni Sosial, Januari 2008 Volume II No 2, 76-82.

Rahman, Anita. (1996). Kiprah Organisasi Islam dalam Pembangunan dalam Perempuan Indonesia: Dulu dan Kini. Gramedia : Jakarta

Sumartono, T. (2005, August 15). Gender di Era Otonomi Daerah. Dipetik August 26, 2005, dari Teropong: www.pikiran-rakyat.com

Susanto, Budi,dkk. (1993). Citra Wanita dan Kekuasaan (Jawa). Kanisius: Yogyakarta

UNDP. (2004). Laporan Perkembangan Pencapaian Tujuan Pembangunan Milenium Indonesia. Dipetik August 26, 2005, dari UNDP: www.undp.or.id/pubs/imdg2004/BI/I ndonesiaMDG_BI_Goal3.pdf+gender + dan + pembangunan $\&$ hl $=\mathrm{id}$

World Bank. (2001). Engendering Development: Through Gender Equity in Rights, Resources, and Voice. Berlin: Oxford University Press.

Instruksi Presiden RI Nomor 9 Tahun 2000 Tentang Pengarusutamaan Gender dalam Pembangunan Nasiona 